\section{Olivier Rabin}

With Beijing 2008 in full swing, the World Anti-Doping Agency's Olivier Rabin is looking for help from the biotech and pharma industry in the battle against cheaters.

As the Olympic torch blazes its way into Beijing this month, doped-up athletes can expect drug testers to be shadowing them like never before. "We've never been in such a good position to catch the cheats," says Olivier Rabin who, since taking up office as science director at the Montreal-based World Anti-Doping Agency (WADA), has worked tirelessly to anticipate the moves of would-be dopers. His efforts are paying off. The number of tests on WADA's antidoping menu is constantly on the rise, an annual increase of $7-10 \%$. Rabin's vision is that science can beat cheating Olympians to the finish line.

Rabin graduated from the University of Paris with a doctorate in applied toxicology, which he followed with a degree in biomedical engineering. He then worked at the National Institutes of Health, in Bethesda, Maryland, from 1993 to 1996, developing pharmaceutical strategies for brain neuroprotection. A move into the commercial sector with Beaufour-IPSEN, in Paris, came next, and in September 2002, Rabin took up his current position of science director at WADA.

His background means he is able to keep abreast of scientific developments and their potential to be abused by the athletes of tomorrow. Since the Sydney Olympics, for example, rumors of 'genetically modified' athletes have continued to surface. Though futuristic, 'gene doping' is a prospect that WADA has taken extremely seriously. "There is a very strong consensus in the antidoping community that DNA transfer will be used for the purpose of performance enhancement in the athletic population," says Rabin.

A core aspect of Rabin's role is to identify research projects, find the staff to take them on and apportion the funding. In previous years, WADA has spent $25 \%$ of its total budget-which this year comes to $\$ 25$ million-on a molecular genetics of doping program, which supports 17 research laboratories. "He's enormously valuable," says Theodore Friedmann, professor of pediatrics at the University of California, San Diego, an authority on gene therapy and head of WADA's gene doping panel. "He plays many, many roles," says Friedmann. "Maybe too many for any one person but he does them all with enormous energy."

WADA's focus is on identifying broad molecular responses that might result from gene therapy, says Rabin. "We will be looking for the effects of gene doping at the genetic level, at the proteomic level and possibly at the metabolic level." It might also be possible to detect evidence of the vector used to carry out a genetic modification, he says. Time is on WADA's side for the moment. "The experts in the field do not have the feeling that it's an immediate threat," says Rabin. "But it's something that will come in the future," he predicts.

So although gene doping remains a distant, but serious threat, WADA has success stories to tell in the run-up to Beijing. Rabin cites the agency's work on selective androgen receptor modulators (SARMs), a novel class of drugs being developed for the treatment of age-related muscle loss and other musculoskeletal wasting conditions.

Aware of SARMs' anabolic potential, he and his team contacted several companies with an interest in these molecules, including biopharmaceutical company GTx, located in Memphis, Tennessee. In collaboration with Merck of Whitehouse Station, New Jersey, GTx has several SARMs in development for a range of indications, two of which are already in phase 2 clinical trials. "Based on the latest information from these companies, we have decided to include SARMs on the list of prohibited substances, even though they are not yet on the market," says Rabin.

With this kind of cooperation, WADA has been able to fund research into the detection of these compounds. One of the researchers involved in this work was Mario Thevis, professor for preventive doping research at the German Sport University of Cologne. "We are now able to detect most SARMs that are currently under clinical evaluation," he says. Because these tests are relatively easy to incorporate into existing screening procedures, they could be added to the menu in Beijing.

This is something that Rabin will neither confirm nor deny, for his job requires plenty of discretion and diplomacy_qualities he will need in abundance to realize his ambition of establishing a framework for a more routine flow of information from drug companies to WADA. "We would now like to move from a case-by-case interaction to a more global approach," he says. "This would require political support from the drug agencies.” It would also require the pharma-

"We will be looking
for the effects of gene
doping at the genetic
level, at the proteomic
level and possibly at
the metabolic level."

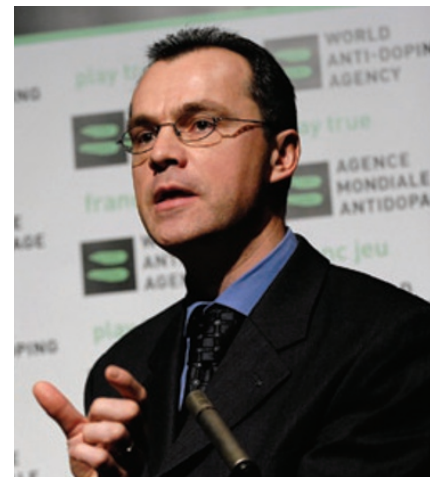

ceutical and biotech companies to have a greater awareness of how WADA operates, the sort of information it needs to develop effective tests and confidence that they can be trusted with their trade secrets. "We are dedicating part of our resources to discuss how such an idea could be put in place."

Rabin has had to hone his detective skills, spreading the net wide to gather snippets of information from wherever he can. WADA receives regular tip-offs, either by telephone or e-mail and occasionally anonymously. Rabin has also met up with doped athletes in an effort to understand what motivates them, how they decide on their doping program, how they obtain access to the substances and how they manage the side effects. "We are connected to customs, police forces, governments and to our colleagues in other antidoping organizations," he says.

The challenge is to integrate the science with these anecdotal leads to produce the most efficient antidoping package possible. "If I look at the past six years, at the way the science has progressed and at the way people tell me that we've never seen such momentum in science and antidoping before, I think we're on the right track," he says.

Henry Nicholls, London 